\title{
Evaluation of the Functional Properties of Bean Starch Zaragoza (Phaseolus lunatus) White Variety in a Food Type Sausage
}

\author{
Yesid Marrugo-Ligardo ${ }^{\# 1}$, Carlos Vargas-Macias ${ }^{\# 2}$, Carlos Severiche-Sierra ${ }^{\# 3}$, Jose Jaimes-Morales ${ }^{\# 4}$, \\ Elias Bedoya-Marrugo ${ }^{5}$

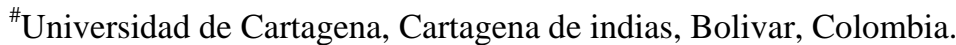 \\ 1ymarrugol@unicartagena.edu.co \\ 2cvargas1@unicartagena.edu.co \\ 33everiches@gmail.com \\ 4jjaimesm@unicartagena.edu.co \\ *Fundación Universitaria Tecnologico Comfenalco, Cartagena de indias, Bolivar, Colombia. \\ *5ebedoya@tecnologicocomfenalco.edu.co
}

\begin{abstract}
A sausage was prepared with the inclusion of different levels of red bean Zaragoza starch $(1.5,2$ and $2.5 \%)$, used as a stabilizing agent in a low fat meat emulsion, to be compared with the sausages of the control treatment. Aiming to establish the ideal concentration and to evaluate the effect of the inclusion of modified red bean Zaragoza starch on the organoleptic characteristics of sausages as well as their effect on the texture of the final product. The experimental results were subjected to analysis of variance, separation of means and descriptive statistics for the tests performed on the final product. It was determined that the levels of modified starch of Zaragoza beans did not affect the nutritional quality of the sausages, which presented on average $57.003 \pm 0.639 \%$ of moisture, $17,073 \pm 0.385 \%$ of protein, $12,791 \pm 0.217 \%$ of fat and $3.678 \pm 0.297 \%$ of starch . Although no significant difference was found in the texture profile analysis, it was found that when the modified starch concentration increased, the product presented an increase in its elasticity and adhesiveness, although for the firmness an equal relation was not obtained, since the Treatment 4 (2.5\% modified starch) had the lowest values, while treatment 3 was the one that obtained the highest values. The sensorial analysis revealed a slightly greater acceptance of the taste by the panelists towards treatment 3 ( $2 \%$ modified starch), however there were no significant differences among the four treatments in terms of the attributes evaluated in the sausages.
\end{abstract}

Keyword- Legumes, Nutritional quality, Proximal analysis, Sausages, Starch.

\section{INTRODUCTION}

Starch At the global level the search for better products, high yields and optimization of raw material has made fundamental the proper use of the ingredients in the formulation of a product [1,2]. Currently the consumer demand for food products with a nutritional balance has been increasing [3,4].

There is a great variety of vegetables in the Colombian Caribbean of which little is known in terms of nutritional quality and its functional properties, therefore they are not optimally used in human food [5]. In other words, few studies are currently focused on the evaluation of the functional properties of food raw materials of mass consumption, which could have great potential in the food industry, becoming alternatives to help in the search for Solutions to food security [6].

Within that list of vegetables we find the Zaragoza bean (Phaseolus lunatus), white variety; There are few studies on the functional aspects of this plant and few elements of technological knowledge on its application in food formulations [7].

On the other hand the national industry uses conventional starches and are mostly imported. For centuries, tropical starches such as cassava, sago, taro, sweet potato and yam have been staple foods for the population in the hot and humid parts of the world [8]. These plants, naturally suited to tropical agroclimatic conditions, grow in great abundance with few or no artificial inputs. Indeed, they are so apt to provide the essential calories, which are considered the quintessence of "subsistence crops" [9].

But in tropical developing countries, the very success of starchy plants as staple foods is limiting their potential contribution to agricultural development and general economic growth [10]. As a result, maize, wheat and potato continue to dominate the lucrative global starch markets of the food and non-food industries. These modern, value-added products usually have very specific applications and are therefore much less susceptible to market fluctuations that may lead to chaos in commodity-based developing economies [11]. 
Transcending this idea that they are subsistence crops and competing with prevailing starches will not be easy, because competition is not in maize, wheat or potato itself, but in the functional characteristics of their valueadded products [12].

Therefore, it is necessary to approach research that favors the use of unconventional starches, in order to give greater added value to them. The objective of this work was to evaluate the functional properties of starch of Zaragoza bean (Phaseolus lunatus) white variety, for which the properties of bean starch in a sausage were determined, the sausage processing process was formulated and standardized. Also evaluating the bromatology, microbiology and sensorially obtained product, finally the texture profile to the final product.

\section{EXPERIMENTAL}

The research was descriptive and experimental, the samples of leguminous Frijol Zaragoza (Phaseolus lunatus) Red Variety, produced in the Colombian Caribbean region. By sample were taken 2 kilograms completely random from the legume and 10 kilograms of meat product.

\section{Obtaining starch}

To obtain the flour, it was carried out in a similar way to that developed by Marrugo et al. (2007) [13]. In Starch extraction, the method reported by Betancur (2001) [14]. was used, this is based on a moist fractionation of the components of leguminous flour, so that after the rest time the sediment rich in starch is obtained.

\section{Preparation of the sausage}

It is made with any type of meat that allows to obtain a paste or emulsion, following this procedure:

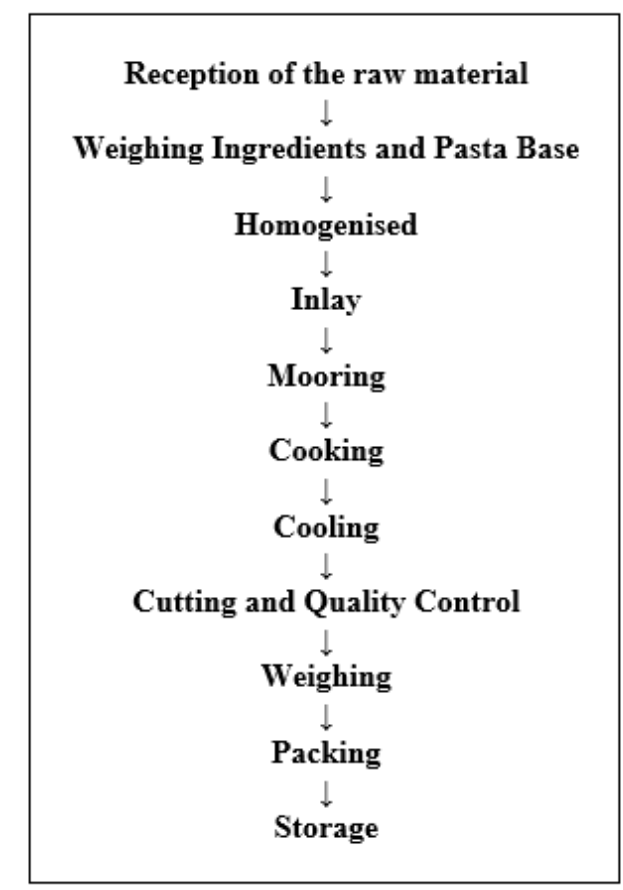

Fig. 1. Sequence of operation for the production of sausages

\section{Bromatological Analysis}

The bromatological tests carried out in this research were: Moisture (AOAC 930.10), Ashes (AOAC 942.05), Proteins (AOAC 984.18) and Fats (Soxhlet).

\section{Microbiological analysis}

Microbiological tests were total Mesophiles (NTC 4519), total coliforms (NTC 4458), Staphylococcus aureus (NTC 4779), Salmonella (NTC 4574) and Listeria monocytogenes (NTC 4666).

\section{Experimental design}

A completely randomized design with three replicates was used, where the treatments used were: F1 with 3.5\% starch of the Zaragoza bean (Phaseolus lunatus) white variety, F2 with 5.25\% starch of the Zaragoza bean (Phaseolus lunatus) white variety, F3 with $7.0 \%$ of Zaragoza starch (Phaseolus lunatus) white variety and a control without addition of the starch of Zaragoza bean (Phaseolus lunatus) white variety, were compared statistically with the objective of establishing the main effects of the treatments during the different conditions and the results allowed to influence whether or not there were significant differences between treatments with a significance level of $\mathrm{p}<0.05$ and a 95\% confidence level. Statistical package SPSS version 15 was used [15]. 


\section{Functional properties of starch}

\section{RESULTS AND DISCUSSION}

The results of the functional properties of white bean starch Zaragoza (Phaseolus lunatus) are presented in Table 1, where the water retention capacity CRA; CRAC is the oil holding capacity; \% Solubility; CG is the gelling ability; Ce is the emulsifying capacity and CEEE is the foamability and foam stability.

TABLE I. Functional Properties of Starch

\begin{tabular}{|c|c|c|c|c|c|c|}
\hline Starch & CRA & CRAC & \% Solubility & CG & CE & CEEE \\
\hline Values & $2.86 \pm 0.32$ & $1.41 \pm 0.63$ & $1.79 \pm 0.21$ & $12.4 \pm 0.73$ & $16.5 \pm 0.46$ & $9.3 \pm 0.18$ \\
\hline
\end{tabular}

Bean starch Zaragoza presented a lower solubility, with a value of $1.79 \%$, as reported by Miranda et al. (2013) [16], due to the size and homogeneity of the starch that intervene in the gelatinization and therefore in its high solubility and high content of Amylopectin (78.19\%) present in the starch granule; Coinciding with the results obtained for bean Zaragoza, by Betancur et al. (2003) [17], where they show that the solubility develops better at temperatures above $80^{\circ} \mathrm{C}$. Researchers raised the possibility that the lateral (amylopectin) branches of starch molecules facilitate the entry of water into intermolecular spaces, increasing the solubility of the polymers, with amylopectin having the highest dissolution rate. This, of course, impinges on the increased solubility of the molecules in water and on the stability of the viscosity [18].

\section{Proximal analysis}

The main purpose of a proximal analysis is to determine, in a food, the moisture, fat, protein and ash content. These chemical procedures also reveal the nutritional value of a product and how it can best be combined with other raw materials to reach the desired level of the various components of a diet. It is also an excellent procedure to perform quality control and determine if the finished products reach the standards established by the control agencies, producers and consumers. In Table 2, the results of the analysis performed on the final product are observed.

TABLE II. Proximal analysis of sausages with starch

\begin{tabular}{|c|c|c|c|c|c|}
\hline Sample & Protein & Fat & Moisture & Ashes & CHOs \\
\hline Treatment 1 & $17.68 \pm 0.12$ & $9.52 \pm 0.09$ & $60.92 \pm 0.20$ & $4.23 \pm 0.15$ & $4.16 \pm 0.09$ \\
\hline Treatment 2 & $17.64 \pm 0.18$ & $9.56 \pm 0.05$ & $61.90 \pm 0.14$ & $4.32 \pm 0.21$ & $5.61 \pm 0.06$ \\
\hline Treatment 3 & $17.61 \pm 0.21$ & $9.54 \pm 0.07$ & $61.67 \pm 0.13$ & $4.44 \pm 0.27$ & $6.89 \pm 0.06$ \\
\hline Treatment 4 (White) & $17.65 \pm 0.27$ & $9.51 \pm 0.06$ & $62.59 \pm 0.16$ & $4.38 \pm 0.29$ & $2.89 \pm 0.04$ \\
\hline
\end{tabular}

In Table 2, it was observed that the treatment presented the highest value of protein fuel treatment [ with 17.68\% followed by treatment 2 with $17.64 \%$, without significant differences between treatments. These values are higher than those established by NTC 1325 (10\%, 12\% and 14\% respectively) and those reported in sausages with modified starch of Zaragoza bean (Phaseolus lunatus) red variety with $12.2 \%$ [19],. In contrast, they are below the values obtained by García et al. (2005) [20], in sausages made with tuna meat and beef (15.53\%).

The percentage of protein between treatments did not change significantly because the same proportion of meat was used for the different treatments, the protein content was due to the percentage of meat used in the formulation, according to García et al. (2007) [21], percentages above 50\% imply an increase in protein content ranging from $15 \%$ or more according to the percentage and type of meat used.

Regarding the fat content, the highest levels were obtained from treatment 2, however, there were no significant differences between the different treatments. It is evident that the level of fat found in the sausages formulated is much lower than the contents reported for sausages made with beef, mutton, chicken and pork, for which values are reported in the fat content ranging from 24 And 45\%. However, it reports values below García et al. (2005) [20], in sausages made with tuna meat (5.15\%). In addition the fat content observed in the sausages obtained was found below the maximum limit allowed by NTC 1325 which is together with the humidity of $86 \%$.

The moisture content of the sausages is closely related to the type of meat ingredient used for their preparation, which are usually classified according to their water retention capacity, ie with their greater or lesser tendency to lose water during The heat treatment, probably these high values in the moisture content may be due to the starch of Zaragoza bean (Phaseolus lunatus) white variety used in the production of the sausages is characterized by a high water retention. However, the high moisture content does not affect the average value in the protein content of sausages (17.64\%), 
It should be mentioned that the moisture content of the starch sausage of the Zaragoza bean (Phaseolus lunatus) white variety did not show significant differences $(p>0.05)$ in the different treatments. This behavior agrees with that reported by Lopez et al. (2016) [22], Domínguez and Gutiérrez (1993) [23], and Magdaleno and Valdez (1994) [24], in meat and fish sausages.

\section{Texture analysis}

In order to observe the behavior of the formulations (T1, T2 and T3) three types of tests were performed: cut, compression and texture profile analysis (TPA) using a TA-XT2i Texturometer (Stable Microsystems, Godalming, UK) $50 \mathrm{~kg}$ load cell, and software provided by the manufacturer (texture experdex ceed, version 2.63) to quantify: hardness (kgf / g), elasticity and cohesiveness (both dimensional).

The texture profile analysis was carried out as follows; Portions of $2.5 \mathrm{~cm} * 2.0 \mathrm{~cm}$ diameter were cut for each formulation. The test consisted in placing each sample in the circular parallel plates of stainless steel of $75 \mathrm{~mm}$ of diameter (a fixed plate and other movable plate) realizing a double cycle compression until the $60 \%$ of the initial height (a cell of $50 \mathrm{~kg}$ was used Whose range was $20 \mathrm{~kg}$ ), with a probe speed of $2 \mathrm{~mm} / \mathrm{s}$, and a waiting time of 2 seconds between each cycle (2 cycles). The following parameters were quantified [25]: hardness (kgf / g or $\mathrm{N}$ ), elasticity and cohesivity (both dimensional).

TABLE III. Texture profile of sausages with starch

\begin{tabular}{|c|c|c|c|c|}
\hline Treatment & Hardness (Kgf / g) & Elasticity & Cohesiveness & Adhesiveness \\
\hline Treatment 1 & $25.7 \pm 0.28 \mathrm{a}$ & $0.76 \pm 0.15 \mathrm{ab}$ & $0.61 \pm 0.10 \mathrm{a}$ & $-0.25 \pm 0.20 \mathrm{a}$ \\
\hline Treatment 2 & $25.9 \pm 0.19 \mathrm{a}$ & $0.74 \pm 0.12 \mathrm{ab}$ & $0.60 \pm 0.05 \mathrm{a}$ & $-0.27 \pm 0.19 \mathrm{a}$ \\
\hline Treatment 3 & $25.8 \pm 0.22 \mathrm{a}$ & $0.75 \pm 0.11 \mathrm{ab}$ & $0.62 \pm 0.08 \mathrm{a}$ & $-0.25 \pm 0.12 \mathrm{a}$ \\
\hline Treatment 4 (White) & $21.2 \pm 0.64 \mathrm{~b}$ & $0.64 \pm 0.17 \mathrm{ab}$ & $0.51 \pm 0.11 \mathrm{ab}$ & $-0.29 \pm 0.18 \mathrm{~b}$ \\
\hline
\end{tabular}

Values are means and standard deviation of 3 replicates. Means with the same superscript in the same column are statistically the same $(\mathrm{P}>0.05)$

As can be observed and according to the statistical treatment the parameters of elasticity, cohesiveness and adhesiveness did not show significant differences, this is due to the fact that the starches are characterized by the property of capturing water and forming gels, great binding power and thickener, Which gives the product a texture and mouth feel similar to that provided by fat. Most of them can not be used in products that are subsequently to be fried, although they can act as a protective layer to avoid the absorption of fat during cooking. They also act by diluting the energy power of fats by replacing them with water, fibers or other less energetic components. The values of the adhesiveness are negative which indicates that the texture of the starch sausage of the Zaragoza bean (Phaseolus lunatus) white variety is sticky or adhesive, that is to say, when the product is consumed it adheres to the palate, which leads to Perform a work necessary to remove it. This may be due to the greater amount of carbohydrates contributed by the starch of the Zaragoza bean (Phaseolus lunatus) white variety.

\section{Microbiological tests}

Three samples of each formulation were analyzed at 48 hours of elaboration, performing duplicate controls of mesophilic aerobes (RAM), total coliforms (CT), Salmonella and S. aureus and Listeria monocytogenes. Following the methodology established by the Colombian microbiological standards (INVIMA and the Colombian Ministry of Health), the results are shown in Table 4.

TABLE IV. Microbiological analyzes of beef sausages at different concentrations of starch

\begin{tabular}{|c|c|c|c|c|c|c|}
\hline \multirow[t]{2}{*}{ Product } & $\begin{array}{c}\text { Mesofilos } \\
\text { Aerobios } \\
\end{array}$ & $\begin{array}{c}\text { Totals } \\
\text { Coliformes }\end{array}$ & E. coli & \multirow{2}{*}{$\begin{array}{l}\text { Estafilococos } \\
\text { c (+) (ufc/g) }\end{array}$} & \multirow{2}{*}{$\begin{array}{l}\text { Salmonella } \\
\text { sp. 25/g }\end{array}$} & \multirow{2}{*}{$\begin{array}{c}\text { Listeria } \\
\text { monocytogenes }\end{array}$} \\
\hline & (ufc/g) & (ufc/g) & (ufc/g) & & & \\
\hline Treatment 1 & 60 & $<10$ & $<10$ & $<100$ & Absent & Absent \\
\hline Treatment 2 & 20 & $<10$ & $<10$ & $<100$ & Absent & Absent \\
\hline Treatment 3 & 80 & $<10$ & $<10$ & $<100$ & Absent & Absent \\
\hline $\begin{array}{c}\text { Treatment } 4 \\
\text { (White) }\end{array}$ & 40 & $<10$ & $<10$ & $<100$ & Absent & Absent \\
\hline
\end{tabular}




\section{Sensory tests}

This test was carried out with a view to measuring the degree of acceptance of beef sausages at different concentrations of white bean starch (Phaseolus lunatus), with an untrained panel of 30 untrained panellists, the results are shown in Table 5. A group of panelists with a 5-point hedonic scale for the sensory evaluation of color, odor, flavor and texture attributes [26].

TABLE V. Sensory evaluation of sausages with starch

\begin{tabular}{|c|c|c|c|c|}
\hline Treatment & Color & Smell & Taste & Texture \\
\hline Treatment 1 & $3.59 \pm 0.17^{\mathrm{a}}$ & $3.69 \pm 0.52^{\mathrm{a}}$ & $4.39 \pm 0.67^{\mathrm{a}}$ & $4.25 \pm 0.48^{\mathrm{a}}$ \\
\hline Treatment 2 & $3.48 \pm 0.23^{\mathrm{b}}$ & $3.75 \pm 0.25^{\mathrm{b}}$ & $4.38 \pm 0.51^{\mathrm{a}}$ & $4.10 \pm 0.49^{\mathrm{b}}$ \\
\hline Treatment 3 & $3.47 \pm 0.19^{\mathrm{b}}$ & $3.70 \pm 0.19^{\mathrm{c}}$ & $4.37 \pm 0.40^{\mathrm{a}}$ & $4.02 \pm 0.65^{\mathrm{c}}$ \\
\hline Treatment 4 (White) & $3.56 \pm 0.31^{\mathrm{a}}$ & $3.80 \pm 0.36^{\mathrm{d}}$ & $4.41 \pm 0.23^{\mathrm{a}}$ & $4.20 \pm 0.71^{\mathrm{a}}$ \\
\hline
\end{tabular}

The evaluation of the color of sausages taking into account Espinosa (2007) [27], who states that the importance of color in sensory evaluation is due mainly to the association that the consumer makes between this and other properties of food, and That sometimes only by the appearance and color of the food, a consumer can reject it or accept it, it is established then that the treatments had a regular acceptance as far as the color, since all the groups of sausages evaluated received an average rating superior to 3.52 points On 5 of reference, which determined that the starch of the Saragossa bean had no effect on this parameter in the sausages. However, there were significant differences $(\mathrm{P}>0.05)$ between treatments 1,2 and 3 due to the different percentages of starch used in each formulation, which may affect the final coloration of the product.

It was evidenced that all the groups of sausages received an average rating superior to 3.69 points on 5 of reference, with a total average score of $3.74 \pm 0.17$, significant differences were registered $(\mathrm{P}>0.05)$ between treatments 1 and 4 , which indicated that the starch of the Zaragoza white bean variety affected this parameter in the sausages.

\section{Conclusions}

All formulations presented good physicochemical quality with a high protein content and low fat content. The sausage presented the best behavior in relation to the addition of starch of the Zaragoza white bean variety, in addition to a better level of acceptance from the sensorial evaluation and even more the one of better behavior in relation to the texture and firmness was the treatment was the treatment 1.

\section{REFERENCES}

[1] I. Baldiris, Y. Marrugo, C. Severiche, J. Jaimes, W. Fong, L. Vargas, E. Bedoya, and H. Cohen. "Delayed Organoleptic Maturation of Tomato Variety Milano (Lycopersicum esculentum Mill) Using Giberelina,” International Journal of ChemTech Research., vol. 10, pp. 1032-1037, 2017.

[2] M. Ma, W. Yijing, M. Wang, J. Jane, and S. Du. "Physicochemical properties and in vitro digestibility of legume starches," Hydrocolloid Foods., vol. 63, pp. 249-255, 2017.

[3] G. Giuberti, A. Gallo, C. Cerioli, P. Fortunati, and F. Masoero. "Quality of cooking and digestibility of gluten-free pasta starch using bean flour,” Food Chemistry., vol. 75, pp. 43-49, 2015.

[4] I. Demiate, A. Figueroa, M. BoffZorté, G. Paes, H. Yangcheng, F. Chang, and J. Jane. "Physicochemical characterization of starches from dry beans cultivated in Brazil,” Food Hydrocolloids., vol. 61, pp. 812-820, 2016.

[5] M. Farid-Sies, N. Asmuin, Fakhrulrazi, N.A. Norsalim, H. Zakaria, R. Pairan, and A. Sadikin. "Determine physical properties of an organic citric acid (processed lime juice) dissolve with water using experimental apparatus," International Journal of Engineering and Technology (IJET)., vol. 8, pp. 2530-2536, 2017.

[6] Y. Marrugo, E. Torregroza, and P. Montero. "Nutritional potential of three Zaragoza bean (Phaseolus lunatus l) cultivars and their in vitro digestibility estimation,” Journal of the Faculty of Agronomy., vol. 29, pp. $314-326,2012$.

[7] J. Jaimes, J. Torres, and C. Severiche. "Analysis of the quality of a scalded meat product made with Prosopis juliflora flour," Ingenium., vol. 9, pp. 21-28, 2015.

[8] J. Jaimes, D. Restrepo, and D. Acevedo. "Preparación y determinación de las propiedades funcionales del concentrado proteico de trupillo (Prosopis juliflora),” Rev.Bio.Agro., vol. 12, pp. 144-152, 2014.

[9] E. Fuentes, M. Riquelme-Navarrete, E. Sánchez-Zapata, J. Pérez-Álvarez. "The Resistant starch as a functional ingredient: a review,” Food Res. Int., vol. 43, pp. 931 - 942, 2010.

[10] Darma, X. Wang, and K. Kito. "Development of Sago Starch Extractor with Stirrer Rotary Blade for Improving Extraction Performance,” International Journal of Engineering and Technology (IJET)., vol. 6, pp. 2472-2481, 2014.

[11] S. Marathe, R. Deshpande, A. Khamesra, G, Sahayog, and N. Jamdar. "Effect of radiation treatment on nutritional, functional, sensory and antioxidant properties of red kidney beans,” Physics and Chemistry of Radiation., vol. 125, pp. 1-8, 2016.

[12] S. Zaman, and S. Sarbini. “The potential of resistant as prebiotic starch,” Crit. Rev. Biotechnol., vol. 13, pp. 1-7, 2015.

[13] Y. Marrugo, E. Torregroza, and P. Montero. "Elaboration of a pate-like food using as a flour extender of the Zaragoza bean Phaseolus lunatus,”@Limentech.,vol. 5, pp. 45-48, 2007.

[14] Betancur-Ancona, D. 2001. Caracterización Molecular, Nutricional y Funcional de Almidones de Phaseolus lunatus y Mucuna purines. México. Tesis (Doctorado en Ciencias, Alimentos), Instituto Politécnico Nacional, Escuela Nacional de Ciencias Biológicas.

[15] D. Ramos, J. Figueroa, J. Véles, and R. Salazar. "Physicochemical properties of nixtamalized black bean (Phaseolus vulgaris L.) flours,” Food Chemistry., vol. 240, pp. 456-462, 2018.

[16] P. Miranda, Y. Marrugo, and P. Montero. "Functional Characterization of Bean Zaragoza Starch (Phaseolus lunatus l) and Quantification of the Resistant Starch,” TecnoLógicas., vol. 30, pp. 17-32, 2013. 
[17] A. Betancur, L. López, and G. Chel. "Comparison of the chemical composition and functional properties of Phaseolus lunatus prime and tailing starches,” Food Chemistry., vol. 82, pp. 217-225, 2003.

[18] Y. Marrugo, E. Torregroza, R. Coneo, P. Villa, and P. Montero. "Obtaining a high protein drink from the Zaragoza bean (Phaseolus lunatus) white variety,”@Limentech., vol. 5, pp. 63-68, 2007.

[19] Y. Marrugo, P. Montero, and M. Duran. "Functional properties of protein concentrates of Phaseolus lunatus and Vigna unguiculata," Vitae., vol. 19, pp. S403-S405, 2012.

[20] A. Garcia, P. Izquierdo, S. Uzcátegui, J. Faría, M. Allara, and A. García. "Formulación de salchichas con atún y carne: vida útil y aceptabilidad,” Revista Científica., vol. 15, pp. 272-278, 2005

[21] M. García, R. Domínguez, M. Galvez, C. Casas and M. Selgas. "Utilization of cereal and fruit fibres in low fat dry fermented sausages,” MeatScience., vol. 60, pp. 227-236, 2007.

[22] J. López, R. Lépiz, D. González, R. Rodríguez, and E. López. "Morphological variability of wild Phaseolus lunatus L. from the western region of México,” Revista Fitotecnia Mexicana., vol. 39, pp. 49-58, 2016.

[23] T. Domínguez-González, and V. Gutiérrez-Giottonini. Elaboración y evaluación de estabilidad de salchichas ahumadas de tilapia (Tilapia sp.). Tesis de Licenciatura, Centro de Investigación en Alimentación y Desarrollo, A.C. 1993.

[24] Magdaleno-Padilla, J. y Valdez-Salazar, R.B. Elaboración de Bolonia a partir de músculo de tilapia (Tilapia sp.) y evaluación de vida de anaquel. Tesis de Licenciatura, Centro de Investigación en Alimentación y desarrollo, A.C. 1994.

[25] Y. Marrugo, P. Montero, and M. Duran. "Nutritional Evaluation of Protein Concentrates of Phaseolus lunatus and Vigna unguiculata," Technological Information., vol. 27, pp. 107-114, 2016.

[26] J. Torres, K. González, D. Acevedo, and J. Jaimes. "Efecto de la utilización de harina de Lens culinaris como extensor en las características físicas y aceptabilidad de una salchicha,” Tecnura., vol. 20, pp. 15-28, 2016.

[27] J. Espinosa. Evaluación sensorial de los alimentos. Sn. La Habana, Cuba. Editorial universitaria. pp 16-24, 2007.

\section{AUTHOR PROFILE}

Yesid Marrugo-Ligardo. Bachelor in Biology and Chemistry, Food Engineer, Food Science and Technology Specialist, Master in Food Science and Technology, he is currently a Doctor of Science candidate at the Dr. Rafael Belloso Chacin University. He is currently a research professor at the University of Cartagena.

Carlos Vargas-Macias. Food Engineer, Young Researcher of the Environmental, Food and Health Research Group MAAS of the University of Cartagena in Cartagena de Indias.

Carlos Severiche-Sierra. He received the title of Chemist from the University of Cartagena, a title of Specialist in Sanitary and Environmental Engineering by the University of Cartagena, the degree of Magister in Sustainable Development and Environment by the University of Manizales, degree Specialist in Health and Safety at Work from the Autonomous University of the Caribbean, he is currently a Doctor of Science candidate at the Dr. Rafael Belloso Chacin University. He is currently a research professor at the University of Cartagena and Comfenalco Technological University Foundation.

Jose Jaimes-Morales. Bachelor in Biology and Chemistry, Food Engineer, Food Science and Technology Specialist, Master in Food Science and Technology, Magister in Chemical Engineering, Master's Degree in Clinical Biochemistry, he is currently a Doctor of Science candidate at the Dr. Rafael Belloso Chacin University. He is currently a research professor at the University of Cartagena.

Elias Bedoya-Marrugo. Doctorate in research and teaching, Magister in integrated management systems, Administrator of Health Services, Esp in occupational health, Esp quality Management and Auditing. Comfenalco Technological University Foundation Faculty of Engineering, Occupational Health and Safety Technology Program, CIPTEC. Position Group: Research Coordinator. 